\title{
George Padmore
}

\author{
Bill Schwarz
}

After a prolonged courtship, on 10 September 1924 in Port of Spain, Trinidad, Malcolm Nurse married Julia Semper. It was a respectable social occasion. The groom was twenty-two (or thereabouts: there is some doubt about his date of birth), the son of a well-regarded elementary teacher, while his wife-to-be was the daughter of the highestranking black man in the service of the island's constabulary. The ceremony took place in an Anglican church, the bride in a lengthy train, the groom in tails. The reception was held in the police barracks on the edge of Port of Spain's Savannah. A few days later Nurse left Trinidad, and his pregnant wife, to travel to Fisk University in Nashville, Tennessee, where he intended to study medicine. Two years on his wife (though not his baby daughter, whom he insisted be christened Blyden) joined him in the US. Gradually, Nurse was drawn into the Communist Party. He acquired a new identity which was to remain with him for the rest of his life: George Padmore. In late 1929 the party gave him two one-way tickets to Moscow. These were stolen, but Padmore scraped together enough cash to cover the cost of a single passage, and he set sail. So far as we can tell he never saw his wife again; was never to see his daughter; and he never returned to the Caribbean.

This represents a particular variant on the theme of emigration which underwrites the story of twentieth-century Caribbean intellectuals. From 1929 to 1933 Padmore energetically devoted himself to the ideals of Soviet Communism, rising high in the firmament of the Communist administration; thereafter, until his death in 1959, his political passions were mobilised in the cause of Pan-Africanism. He was an intellectual formed deep in the vortex of the age of extremes, and for most of his life he espoused positions which others perceived to be both extreme and fanatical. His politics forced an abrupt separation from the modes of life which an aspiring colonial professional would have anticipated: his future experience of police barracks was to be 
more conventional. As much as his boyhood friend, C. L. R. James, Padmore fashioned himself as a universal intellectual, driven by the constraints imposed by colonial locality to imagine a larger world.

For good reason, James is regarded as the magisterial, worldhistorical intellectual of the twentieth-century anglophone Caribbean. But James's life moved in tandem with Padmore's. They grew up together, both the sons of elementary teachers. They both arrived in London for the first time in 1932: James to begin his career as a writer, Padmore from Moscow, on an official assignment for the Red International of Labour Unions (RILU). James recounts his surprise, turning up to a political meeting in Gray's Inn Road, to find that the speaker, billed as George Padmore, was none other than his childhood friend. They worked closely together from 1935, when Padmore first settled in London, to 1938, when James departed for the USA. Even during the war, with the Atlantic dividing them, they were in close contact.

The relationship with Nkrumah is instructive. James had got to know Nkrumah in Harlem. When in 1945 the latter decided to journey to London it was the most natural thing in the world for James, in effect, to pass him on to Padmore. Arriving on the boat-train at Euston station Padmore was waiting for him, initiating a political intimacy which survived many tests. In 1953, when in turn James returned to Britain, his friendship and political collaboration with Padmore picked up again. They were both with Nkrumah in Accra the night that Ghana was founded, on 6 March 1957, invited to witness the birth of the black nation.

These convergent trajectories tell us something about the unreconciled commitments of Caribbean radicalism, pulled both by socialism and by the imperatives of black emancipation. They tell us something too of the extraordinary journeys James and Padmore made, which could barely have been imagined in turn-of-the-century Tunapuna. After Padmore had died James planned to write the story of his life. As editor of Trinidad's People's National Movement paper, The Nation, he immediately contributed a long-running series entitled 'Notes on the life of George Padmore'. ${ }^{1}$ Those close to James believe that by late in the 1960s the bulk of a biography had been drafted. ${ }^{2}$ That it remained unfinished may have something to do with the fact that in telling Padmore's life, James would also have been narrating his own. In a lecture delivered in 1971 - in a strange, passing formulation - James alluded to this interweaving of their lives by declaring that if he were to work further on Padmore he might make it 'into an autobiography'. ${ }^{3}$

More particularly James's esteem for Padmore knew no bounds. When The Nation announced Padmore's death it not only described him, in 
words which undoubtedly were those of James, as 'a great gentleman' and 'a great citizen of the world', but also - 'with the exception of Marcus Garvey' - as 'the most famous West Indian of all time'. ${ }^{4}$ Almost a decade later, in first naming the tradition of West Indian intellectuals whom he believed constituted the rightful heirs of John Jacob Thomas, James identified the following figures: Garvey, Césaire, Padmore and Fanon. Readers may know of Garvey, Césaire and Fanon. Padmore, on the contrary, barely registers in contemporary historical memory. James's tributes to those who moved him could be pardonably excessive. But what of Padmore? And what of Padmore's conception of the civilisation of the British?

In V. S. Naipaul's Mimic Men the father of the narrator walks out of his job at the Department of Education on the imagined locale of Isabella in order to become a millenarian street-preacher and agitator in the dock-strike of the late 1930s. His son, who narrates the story, was (we learn) deeply affected by this collapse in his family circumstances and thereafter proved to be duly sceptical of politics, especially a politics which purported to be anti-colonial. 'On the subject of empire', he claims, 'there is only the pamphleteering of churls. ${ }^{5}$ For Naipaul nothing could be more demeaning; for his compatriot, Padmore, the role of churlish pamphleteer, far from being an insult, signalled virtue and probity.

There are hints that whilst in Trinidad Padmore carried some formal commitments to black emancipation. In later life he talked much about the fact that his grandfather was a slave. He claimed, too, Henry Sylvester-Williams (the inspirational figure who inaugurated the first Pan-African Congress in London in 1900) to have been an uncle. His father converted to Islam searching, it seems, for a means to efface the inheritance of slavery. Certainly, we know that his father possessed an extraordinary library, which was used by both his son and by James. It is very likely that this contained classic writings of black intellectuals. James certainly recalls Padmore reading DuBois and Garvey whilst he was still in Trinidad. Padmore's insistence that his daughter be named after the early intellectual of black nationhood, Edward Blyden, is suggestive. But much of this is evidence cited retrospectively.

Padmore was inducted into politics in the USA and through Communism, though from the outset he was fired by the injustices of race and colonialism. In his early commitments no moment of equivocation is apparent. By 1928 he was prominent within the milieu of Harlem Communism, and when he travelled to Moscow he went as an expert on the colonial and racial question. His main task was to direct RILU's Negro Bureau. He lectured to classes of visiting colonials. He may have arranged Kenyatta's first visit to the Soviet Union in 1929; 
certainly, he was Kenyatta's main contact on his second journey in 1932-33, his (Kenyatta's) biographer describing him as 'Padmore's protégé'. ${ }^{6}$ Formal honours came his way: he was positioned on the central podium in Red Square one May Day, and (with Stalin) elected to the Moscow Soviet - his lack of Russian notwithstanding. He conducted many clandestine missions throughout Europe, and perhaps beyond, though he made the port-city and Communist stronghold of Hamburg his principal base, organising there in July 1930 the first international conference of Negro workers, a ramshackle affair but a landmark nonetheless. A year later, from Hamburg, he was editing for RILU the monthly The Negro Worker which, in the name of Communism, served as the organiser of the black masses throughout the Atlantic world. It was in Hamburg too that he was arrested, just at the moment when the Nazis acceded to power. He was fortunate to find himself deported to Britain, the Consul-General in Hamburg cabling the Foreign Office to inform them that Nurse (not Padmore) was on his way, and that 'Steps are being taken to safeguard his trunk which contains Communistic correspondence' ${ }^{7}$.

The seditious trunk is significant. Insurgent literature, coupled with sophisticated skills in organisation, represented Padmore's great strengths. Through his life he read everything he could find on the colonial situation. His speciality was to burn through official reports and statistics, turn them inside out, and reveal from the sources of the colonialists themselves the iniquities of colonialism. He wrote ferociously. Much was unsigned. After the break with Communism, he was in the habit of composing journalistic articles at great speed, making five or six carbon copies, and sending them to contacts throughout the world, in the hope that a portion of his output would be published - attaching to each article the request: 'Please pass on to other periodicals'.

Padmore's characteristic mode of writing is not easily accommodated to contemporary sensibilities. His relentless denunciations of colonial exploitation, and the frequently instrumental reasoning he enlisted in order to effect his critique, do not readily conform to current habits of thinking which emphasise the equivocal, the ambivalent and the contingent. This was a mode of writing which had been tutored in an exclusively Communist pedagogy, and which existed on the political extremities. But posterity can be condescending.

There is evidence, for example, that Padmore's contemporary readers could engage with his writings in ways which are not readily available to us today. Ras Makonnen provides some clues. Makonnen himself was a close collaborator of James and Padmore, an integral figure in the West Indian networks in Britain in the 1930s and 1940s, who migrated to Ghana at the time of independence and thence, following Nkrumah's 
downfall in 1966, to Kenya. Makonnen, born George Griffith in British Guiana at the turn of the century, was a West Indian of many talents, whose intellectual biography fits centrally into the themes addressed in this volume. Toward the end of his life he recounted his own vivid story. In so doing he recalled the moment when, in the United States in the early 1930s, he picked up and read Padmore's The Life and Struggles of Negro Toilers.

This was a book which arose from the Hamburg congress, written at the instigation of the RILU, and published in 1931. Its purpose was to reveal the exploitation of the world's two hundred and fifty million Negroes, as Negroes. Padmore argued that they were exploited as a class and as 'a nation', though locating the ultimate source of oppression in the systems of capital. This entailed his reviving the classic marxist interpretations of imperialism, though positioning race oppression at the analytical heart of his understanding of capitalism. These theoretical postulates are briefly laid out in a few opening pages. The greater part of the book delivers an empirical, synoptic view of the exploitation of black workers in Africa, the USA and the Caribbean. It concludes, as one might expect, that the revolutionary potentiality of the oppressed was in place. Thus, writing on South Africa, his confidence in the future remained characteristically undimmed: 'every act of Pirow, Hertzog, Smuts and Co merely increases the revolutionary mood of the masses'. Padmore warned his readers to be alert to the dangers of Garveyism /the struggle against which 'represents one of the major tasks of the Negro toilers in America and in the African and West Indian colonies'), which was to be equated to the dangers of Gandhism (representing the 'class interests of the black bourgeoisie and landlords' ${ }^{8}{ }^{8}$ These were views which were to be found in every page of The Negro Worker: the revolutionary capacities of the black masses were on the brink of realisation, held back only by the machinations of the false leaders - DuBois, Gandhi and, in Britain, Harold Moody. ${ }^{9}$ Revolutionary optimism went hand in hand in with sectarian denunciation, and both were driven by an unremitting class reductionism in which racial chauvinism was explained as the tool of a ruling class on the run.

But for Makonnen, and for those similarly minded, Padmore was 'a revelation'. Makonnen guessed from what he experienced as the vitality of the writing that the author of The Life and Struggles of Negro Toilers must have been his old friend Nurse (whom he had probably first encountered at Howard University). 'It was almost as if he had invented a new dictionary of terms with which he could burlesque the chiefs and yes-men of the various colonial regimes.' There was emphatically a 'magic' about Padmore. ${ }^{10}$ 


\section{GEORGE PADMORE}

Five years after The Life and Struggles of Negro Toilers Padmore published, in 1936, How Britain Rules Africa. Interviewed in the 1970s Makonnen still felt the force of this latter book. It guided 'many of us' for years after; 'here was the anatomy of our misery laid bare'; it marked a kind of 'Magna Carta', leading those it spoke to from 'darkness'. 'I still feel the impact of that book upon us. It was part of our spiritual campaign. ${ }^{11}$

Makonnen was not an uncritical thinker. His judgements on old friends could be harsh. On specifics he thought Padmore misguided, and - in one unexpected scenario - he took Padmore to task for vacillating on his commitments to the anti-colonial struggle. ${ }^{12}$ His regard, in consequence, is the more convincing. Nor was Makonnen unique in his opinion of the quality of Padmore's insights. It's clear that the editors of journals to which Padmore contributed believed him to be an original thinker, of unusual intelligence and force.

Between the writing of The Life and Struggles of Negro Toilers and How Britain Rules Africa Padmore was expelled from the official Communist movement. After the Nazi party took power in Germany in January 1933 Moscow slowly began to lessen its vilification of the democratic nations of Western Europe, as a prelude to the later popular front strategy in which all enemies of fascism - socialist and nonsocialist - would seek to unite in order to defeat the greater enemy. This reversal in the policy of the Communist International demanded also that hostility to the colonialism of the western European powers be suspended, winding back across the globe Moscow's support for antiimperialist campaigns. In consequence, the Negro organisations which Padmore had animated were disbanded. On hearing this, in August 1933 , he immediately resigned all his offices; his formal expulsion was set in motion in February 1934; and thereafter denunciations of him began to appear in the official Communist press.

From this time on, Padmore determined that the struggle for black emancipation could in the future never be subsumed to any other political force: blacks themselves needed to create their own autonomous organisations, free to operate as they saw fit. This shift in Padmore's thinking caused a more respectful position on Marcus Garvey to evolve - though both he and James were vociferous in condemning Garvey's conservatism during the outbreak of strikes and riots in the Caribbean in 1937 and 1938. ${ }^{13}$ More importantly it took Padmore close to his erstwhile antagonist, W. E. B. DuBois. His had been a politics which had always been sympathetic to the ultimate aims of Pan-Africanism, even when sectarian denunciation had been in order. But from this time on, organisationally, he moved swiftly from Communism to Pan-Africanism.

Yet as Padmore crossed the threshold into the arena of Pan-Africanism 


\section{BILL SCHWARZ}

he took with him many of the political categories of orthodox Bolshevism. He never expressed disillusionment with the basics of the marxism he had learned as a militant in the Communist movement. He continued to regard Lenin as the greatest political thinker of the century. ${ }^{14}$ Though Padmore was not an intellectual given to abstraction, the classical marxist theories of imperialism, generated in the decade before the first world war, worked in his imagination as the logical starting point for an explanation of the global political realities of his own times. The underdeveloped and colonial world functioned, he believed, as the source of 'super-profits' for the metropolitan powers, and in the process created the conditions for buying off or for 'bribing' the labour leaders of the metropolitan working class - a conviction which remained with him long after he left the ranks of Communism. ${ }^{15}$ But if the earlier emphasis of the classical theorists of imperialism had been on the global circuits of capital and on the various manifestations of financial capital, the emphasis Padmore offered was significantly different. His defining analytical and political category was the concept of exploitation. For Padmore, capitalism was a system predicated on exploitation; those most exploited inhabited the colonies; and of these, black Africans constituted 'the most oppressed of the Earth'. ${ }^{16}$

Padmore's journey from Communism to Pan-Africanism required continuous rethinking of political strategy, evident in his deepening commitments to the self-activity of the black masses. But the transition from one to the other did not bring with it dramatic conceptual renovation. From the start of his political life, colonial and racial issues had dominated his thinking. As the world crisis developed through the 1930s, while others were tempted to relegate colonial matters as secondary, or peripheral, Padmore reaffirmed their indispensable centrality. In so doing, he translated the categories of his Communist days into the idiom of Pan-Africanism.

Above all, he stretched the concept of fascism such that it would illuminate the historical realities of the super-exploited of the underdeveloped world.

His first sustained interpretation of fascism appeared in an unsigned editorial of The Negro Worker in April and May of 1933, in which he was at pains to draw out the centrality of race to the Nazi order:

Most Negroes in Europe and America as well as in the colonies do not yet fully realize that fascism is the greatest danger which confronts not only the white workers, but it is the most hostile movement against the Negro race.

The most glaring manifestation of this anti-Negro feeling is to be seen in the Hitler movement in Germany. Even before the fascists came into power in Germany, they carried on the most violent agitation against 


\section{GEORGE PADMORE}

Negroes, Jews, and all so-called non-Nordics. But since Hitler has become Chancellor, this Nazi agitation has taken on the form of open physical violence against all colored peoples ... the fascists in Germany are preaching race hatred and advocating lynch law. ${ }^{17}$

There is no evidence that either Padmore or The Negro Worker intended to offer theoretical reflection on the specific phenomenon of fascism. The term was invoked as a practical concept, fashioned on the run, to describe observable political realities and to signal the deepening authoritarianism of European politics - though having been jailed in Hamburg, Padmore had experienced the intensification of repression first-hand. Even so, his reading of the situation was striking, for he indicated that from the outset the decisive feature of the new regime in Germany was its dependence on the institutions of internal racial terror.

Like many blacks of his generation, Padmore was convinced that the Italian invasion of Abyssinia in October 1935 marked the critical watershed in the breakdown of the international situation. In May he contributed an article to The Crisis, the organ of the National Association for the Advancement of Colored People, warning of the dangers to come. Fascism, he declared, was already the dominant political force in Europe. However, its immediate fate, he believed, was to be decided in the underdeveloped world of Africa and Asia - in Abyssinia especially. If Abyssinia were to be defeated, the dominance of fascism in Europe would be consolidated. In this crisis, he wrote, the 'racial aspect looms large'. The destruction of Abyssinia would represent not only a regional victory for a fascist power but, more generally, the reassertion of the larger colonial authority of 'the white race' and the vindication of 'aggressive nationalism' and 'territorial expansion'. ${ }^{18}$ These themes recurred in his writings in the next few years. He determined to show that the collapsing international order was inseparable from the colonial rivalries of the European powers. ${ }^{19}$ But as the Abyssinian crisis unfolded there occurred an important shift in his thinking. The democratic powers, and their collective diplomatic representative the League of Nations, had failed to intervene to save Abyssinia. Padmore saw this as a betrayal - in much the same way as the European left saw the destruction of Czechoslovakia in 1938. Padmore concluded, however, that the European powers - fascist and non-fascist - were equally culpable in their disregard for colonial peoples. ${ }^{20}$ This is what Abyssinia had demonstrated to him. In his final days at The Negro Worker he had identified fascism as 'the greatest danger', a danger located in the Nazi state. After Abyssinia fascism acquired a broader meaning for him, indicating not only the type of political regime evolving in Germany and Italy, but a racial politics 


\section{BILL SCHWARZ}

linked to colonialism itself. This represented a radical reappraisal. From this shift in thought there emerged a sharper theoretical critique of the civilisation of imperial Britain; there also appeared, alongside it, a more rigorous scepticism toward the anti-fascism of the mainstream left, which in turn would take him, in 1939, to a principled refusal to support the Allied cause.

It was from these years that Padmore's peculiar pre-eminence as the arch-agent of African decolonisation became established. From 1935 he settled in London - first setting up in Guilford Street, which is where J. J. Thomas had lived at the end of the previous century, and then adopting a more permanent base at Cranleigh Street, just north of Euston station, handy, perhaps, for the boat-train from Harlem. In the summer of 1935 he joined the International Friends of Abyssinia, which had been launched by three West Indians (James, Amy Ashwood Garvey and Sam Manning) and two Africans, Kenyatta and Wallace Johnson. Padmore's authority on these matters quickly made itself felt to the others and when, in May 1937, the body broadened its ambit by renaming itself the International African Service Bureau (IASB), Padmore was the natural choice to chair it. Prominent Britons of left sympathies were invited to act as patrons: Sylvia Pankhurst, Nancy Cunard, Arthur Creech-Jones, D. N. Pritt and Victor Gollancz. Makonnen's business skills kept the organisation in funds. Padmore's activity comprised much the same as when he had been editing The Negro Worker - though he could no longer rely on the institutions of the Communist International. It was at this moment especially that he came into his own as a world-historical individual, the endless source of news, advice, addresses, contacts, such that countless of Africa's itinerant rebel intellectuals felt obliged to make the ritual journey to Cranleigh Street. Or as this was put in the unflattering prose of Jamaica's Daily Gleaner, he became 'some sort of master termite hidden in the recesses of a vast network of friendships', directing or encouraging 'a considerable revolution in the colonial world and more particularly in the British colonial world ${ }^{\prime 21}$ In the process he became a mythic being. ${ }^{22}$

James commented on the oddity of the fact that three West Indians - himself, Padmore and Garvey - should fight out the distant battles of the Caribbean, during the upsurge of rioting, at Speakers' Corner in Hyde Park. Even more strange was the hubris of this tiny group of West Indians, in the IASB and its forerunners, in turning their attention to the entire stage of Africa, believing that they had it within their grasp to organise the emancipation of a continent. I'll come back to this.

In the mid 1930s both Padmore, after his break with Communism, and James moved into the orbit of the Independent Labour Party (ILP), 


\section{GEORGE PADMORE}

which encouraged the expression of non-Communist variants of marxisant politics, and which was more ready than its rival organisations to concede the importance of 'the colonial question'. James first contributed to the ILP's New Leader in October 1935, just at the moment when Italian troops had crossed the Eritrean border and invaded Abyssinia. (Underneath the minuscule photo of James the editor, Fenner Brockway, explained that James was chairman of the Finchley branch of the ILP and that 'he writes fiercely'.) James confronted the veteran imperial ideologue, J. L. Garvin, and argued that the League of Nations itself had become a new tool of imperial aggression - a theme he was to develop over the weeks which followed. ${ }^{23}$ At the start of 1936 he also alerted the readers to the duplicity of Stanley Baldwin, warning them that this 'perfect master of the sleight-of-hand' was nothing but a deep 'reactionary' encouraging the sub-editor to flag his article with the imperative: 'Look out for fascist developments!' ${ }^{24}$ Padmore - despite lambasting Brockway in How Britain Rules Africa - started writing for the ILP's Controversy early in 1938, commenting on the government inquiries into the previous year's riots in Trinidad. Unlike James, Padmore never hinted that a domestic, British version of fascism might be just around the corner. But Padmore had no inhibitions in drawing on an expansive idea of fascism in order to demonstrate that contemporary colonialism - British colonialism included - was on the point of transmuting into a mode of fascism.

In Trinidad, for example, he believed that the government was 'inaugurating a policy which savours of Colonial Fascism'. ${ }^{25}$ In How Britain Rules Africa he explained how in the settler colonies there existed the inescapable presence of 'stark imperial oppression and exploitation, allied with racial ignorance and arrogance, swaggering about without the least sign of shame'; they functioned as 'the breeding-ground for the type of fascist mentality which is being let loose in Europe to-day' ${ }^{26}$ In South Africa, where exploitation was more extreme, he declared that the 'unity of race as against class accounts for the widespread racial chauvinism which permeates all strata of the European population, and makes the Union the world's classic Fascist State'. ${ }^{27}$ South Africa and Southern Rhodesia were totalitarian 'long before Hitler began to institute similar methods in Europe' ${ }^{28}$ From about the end of 1939 Padmore regularly equated the suffering of Jews in Germany with blacks in the British colonies, especially those in the white settler societies. In an article which carried the title 'The British empire is worst racket yet invented by man' he indicted the British for exercising in southern Africa the 'most blatant expression of racial superiority', which produced for the blacks a situation 'more tragic even than that of the Jews under the swastika' ${ }^{29}$ In the following year he asserted that there 


\section{BILL SCHWARZ}

existed an 'indissoluble link' between the populations ruled by the Nazis and 'the right of coloured races to self-determination'. Those who had failed to appreciate this had, he claimed, 'objectively assisted the onward march of Fascism'. ${ }^{30}$ Or as he concluded in 1941: 'Wherever Imperialism operates, Nazi methods are to be found ${ }^{\prime}{ }^{31}$

For one prone to employ orthodox marxist categories, this interpretation of South Africa - and of fascism - is in fact strikingly heretical. Today, readers coming across such statements will be wary. (Though when Fanon arrives at much the same conclusion about the connections between colonialism and fascism, via more elaborately philosophical routes, it feels rather different.) Charges of fascism have been so common, and are often so reductive, that they rarely enlighten political thinking. As I've suggested, Padmore employed the term as a practical category, without much heeding the specificities of its European forms. But this shouldn't conceal the insights which his approach delivered. Fundamentally, fascism for Padmore represented state-directed racial supremacy, in which a dominant ethnic group enslaved a subordinate ethnic group (by employing extra-economic means, including terror, to compel it to labour) on the sole basis of its putative racial identity. From this perspective, South Africa could indeed be regarded as exemplifying a classic fascism, as could Germany, while elsewhere in the British colonies there occurred, in more restricted form, policies which 'savoured' of colonial fascism (Trinidad), or social mentalities which might in the future 'breed' colonial fascism (the white settler colonies). Within this reasoning, fascism was a term which had no direct application to the historical conditions of metropolitan Britain itself. ${ }^{32}$

The conviction that the will for racial purity lay at the core of fascism is powerful, conforming to certain currents of postwar European philosophy. ${ }^{33}$ It worked to question the notion that fascism was a peculiarly German, or continental, phenomenon. Commensurately, it questioned the integrity of much of the anti-fascist folk-wisdom common in Britain from the mid 1930s to the mid 1940s, disclosing the repeated moments when Britain's vaunted democratic values buckled under the pressure of dangerous racial imperatives. In the closing pages of How Britain Rules Africa Padmore had expressed the hope that 'this book will serve to throw light into dark places'. ${ }^{34}$ Makonnen echoed this when he claimed that Padmore possessed the ability to lay bare the 'darkness' of black subjugation. This, I think, explains Padmore's originality, and the source (for his contemporary readers) of his revelatory powers. His conjoining of Bolshevism and Pan-Africanism allowed him to become not merely the chronicler of the immiseration of the colonised, but - in a Gramscian sense, taking Padmore truly to be an intellectual organic to a larger, anti-colonial movement - the philosopher of 


\section{GEORGE PADMORE}

the 'dark places' of empire in general, and of the British empire in particular. This was a philosophy which carried its appointed language, or as Makonnen put it, one which comprised a 'new dictionary of terms'. It strove to demonstrate that the darkest region of all resided deep in the imaginings of white civilisation.

Padmore had the knack for making speakable what previously had been unspeakable, and for shifting the terms of public debate. In relation to black Africa he sought to overturn the accepted wisdom on the polarity between civilisation and barbarism. And we can see something similar in his determination to portray the white settlers - in South Africa and Southern Rhodesia especially - not as the vanguard of English civilisation, exemplars of quiet fortitude and broad humanity, but as arrogant, swaggering racial chauvinists barely indistinguishable from Aryan thugs closer to home. To speak in these terms, in the 1930s and 1940s, constituted an astounding provocation. ${ }^{35}$

We don't have to share Padmore's judgements, nor do we need to endorse the political positions to which he journeyed. But we should recognise what he represents. There were before him, of course, many different currents of anti-imperial thought in Britain, the greater number of which derived from liberal or radical-liberal traditions. While these could be fierce on empire, on matters of race they often equivocated, attached at a profound level to a belief in the essential moral superiority of the civilisation of the English. In elaborating a political philosophy in Port of Spain, Harlem and Moscow Padmore brought into England systems of thought from outside, and although many ambiguities remain, the extremity of his views was supremely un-English. More particularly, this enabled him, and those won to his cause, to disengage from the presiding Westminster vision of the colonial world which, while deeply liberal in its precepts, insisted that independence for the colonies had to await the attainment of a requisite level of civilisation. Padmore, to the contrary, declared that independence should be immediate, 'regardless of their social and cultural development' ${ }^{36}$ Rather than assuming that emancipation was the gift of London he insisted that the black masses were the agents of their own liberation. ${ }^{37}$ This determination to seek equal moral worth in the voice of the black masses of Africa was (and perhaps still is) the source, in part, of Padmore's 'magic'. It created the conditions in which 'the chiefs and yes-men' of the British empire could - in a nice West Indian turn - become the object not of reverence but of what they merited: 'burlesque'. 'Imagine', wrote Makonnen, 'what it meant to us to go to Hyde Park to speak to a race of people who were considered our masters, and tell them right out what we felt about their empire and about them. ${ }^{38}$ 


\section{BILL SCHWARZ}

Padmore's refusal to accept at face value the founding myths which gave life to colonial aspiration made new thought possible. An early witness to this was Stafford Cripps in 1937, momentarily espousing a role as outrider to the left sects. He contributed a foreword to Africa and World Peace in which he commended Padmore's 'courageous exposure of the great myth of the civilising mission of western democracies in Africa' ${ }^{39}$ Much later, in commenting on the success of the independence movement in Ghana, James picked up this notion of myth, and attempted to explain what it entailed and how it worked.

One of the greatest modern myths has been the myth justifying and even ennobling 'colonialism' or, as it used to be called, 'the white man's burden'. At present it is a common belief that colonialism in the modern world is dead or dying.

Nothing could be further from the truth. Colonialism is alive and will continue to be alive until another positive doctrine takes its place.

The power of the myth of colonialism, James continued, derived from the fact that it worked beyond the reach of reason, or of rational critique. Those who propagated it were neither hypocrites nor liars: on the contrary, they lived within the 'unconscious premise' of the myth itself. 'It is not that the myth is not challenged. It is, but almost always on premises which it has itself created, premises which, as with all myths, rest on very deep foundations within the society which has created them.' The myth of colonialism, he argued specifically in relation to Britain, 'is now an organic part of the thought processes of the nation and to disgorge it requires a Herculean effort'. 'It must', he concluded, 'be routed, torn up by the roots, ridiculed. ${ }^{40}$ Both James and Padmore worked to make conscious the 'unconscious premise' of the myth of colonialism, and to step outside its givens: to effect, in other words, the intellectual labour of decolonisation.

In outline, with necessary brevity, I've described the main contours of Padmore's political thought from the days of The Negro Worker to the time of the Pan-African Congress in Manchester in October 1945. The Congress marks a turning point in Padmore's political life. Present were Nkrumah, Kenyatta and Hastings Banda - all poised to return to their home nations. DuBois and Amy Ashwood Garvey presided. The congress represented a direct continuation of the one organised by Padmore in Hamburg fifteen years earlier. (Though perhaps a little less ramshackle: the proceedings carefully record that $£ 4-10-0$ was spent on 'bunting and flags' and rather more - £4-15-0 - on the services of the local Red Cross band. ${ }^{41}$ It continued too the remarkable preponderance of West Indians in the Pan-African movement: of the fifty-eight accred- 


\section{GEORGE PADMORE}

ited delegates, thirty-three were from the West Indies. But the following year Kenyatta returned to Kenya, and the year after that Nkrumah to the Gold Coast. Each became the principal actor in their respective national struggles for independence - 'moving out from London to declare war on the empire' ${ }^{42}$ Thereafter Padmore poured his energies into supporting Nkrumah in the Gold Coast, preoccupied with the internal demands of a political movement, but certain in his own mind that a lifetime's work was on the point of fruition. When success came in 1957 he could reasonably have thought that the emancipation he had dreamed of had become a historical reality - that they'd done it. Writing in Présence africaine in 1957 Padmore likened Nkrumah's autobiography to Tom Paine's Common Sense, the detonator which would set in train a continental revolution: 'L'indépendence du Ghana est justement le commencement de la liberté pan-africaine ${ }^{\prime}{ }^{43}$

But for my purposes two interconnected questions remain outstanding. First, there is more to say about Padmore's conception of the British at home; second, is the matter of his West Indian provenance. Certain ambiguities arise.

We can return for a moment to the image of the young Malcolm Nurse on his wedding day, bedecked in tails in the Anglican church in Port of Spain. It offers a perfect snapshot of early twentieth-century colonial respectability. As we have seen, shortly after the wedding Malcolm Nurse transmuted into George Padmore, the Bolshevik agitator. But perhaps it is wrong to suppose that the identity of Malcolm Nurse, the respectable anglo-colonial, was entirely extinguished. The doubleness of Nurse-Padmore is important. James caught something of this in his eulogy, describing Padmore as simultaneously 'a great citizen of the world' and 'a great gentleman'. Padmore, James implied, embodied both a Jacobin spirit of insurgent, republican virtue and the lived forms of English gentlemanliness. To later generations this looks like a fusion of contraries, though it was clearly important to James, as it was to Padmore himself. All the reports of Padmore - firebrand politics notwithstanding - depict a man of deep courtesy, given entirely to English manners. 'A British West Indian of the old school', as James remarked later. ${ }^{44}$ To Makonnen he appeared 'spick and span like a senator' ${ }^{45}$ Padmore never boasted, as James did, that he read Vanity Fair each year. Indeed, there was the suggestion that he affected a revolutionary disdain for the cultural artefacts of England. But James was never persuaded by this; and it is significant that in the brief obituary carried in The Times mention should have been made of Padmore's love for English literature. ${ }^{46}$ In short, Padmore showed every sign that he had mastered the culture of the colonisers, having learned to inhabit Englishness at perfect pitch. 


\section{BILL SCHWARZ}

For Padmore as much as for James mastering the codes of England provided a way out from colonial Trinidad. Describing Padmore's situation in Trinidad, and his own, James noted that 'a proud and sensitive black man could feel a sense of intolerable restriction', which is about as near as he ever got in public to revealing his experiences of racial subordination..$^{47}$ For James coming to England, and coming to inhabit the civilisation of the English at its epicentre, were the means by which he fashioned himself as a modern being, in opposition to what he had experienced as colonial provincialism. There was something of this in Padmore too. We can catch a glimpse of it in the accounts of his relations with white English women - with Nancy Cunard (who faithfully typed out the entire manuscript of How Britain Rules Africa) and, most of all, with Dorothy Pizer, whom Padmore met in the late 1930s and later married. Pizer personified the attributes of the 'modern woman', 'a Londoner and sophisticated to the last degree'. She worked - on her own terms - as secretary to a 'big businessman'; she dressed with fashionable taste; she was an accomplished cook, learning how to prepare West Indian and Indian dishes; she had a facility for languages; after the war she persuaded Padmore to tour Italy. This talented woman of independent views chose 'to subordinate herself ... entirely to George and his work', earning the bulk of the money which kept them going. She contributed vast amounts of editorial work, did many if not all of the translations, and (once or twice) claimed sole or partial authorship. Although 'she didn't find it easy', she expended much labour cooking for their myriad of visitors, demanding only that George did the washing-up. On politics, she reserved the right to argue 'vigorously'. ${ }^{48}$ This was essentially a modern, cosmopolitan, London relationship, far removed from the expectations of colonial Trinidad. In both the US and in the Soviet Union Padmore had experienced new freedoms: but in England too this 'British West Indian of the old school' was able to fashion his selfhood through his inhabitation of Englishness and to present himself as a fully modern - that is, a non-colonial - figure.

Except that this affiliation to modern selfhood was vitiated by race. Nurse-Padmore had a double existence, simultaneously located in and dislocated from his English way of life. Padmore - like James; like their shared foe Harold Moody; but unlike a later generation - did not easily find a voice in which this ambivalence could be spoken. On the one hand he could unleash his incessant indictment of the racism of empire, while on the other suggest that, in daily life, to complain about one's own experiences was to compromise one's integrity as a colonial whose colonial origins had been transcended. To rise above the pettiness of racial injustice was confirmation of one's having overcome colonial identity, testament to one's advanced viewpoint. On this Padmore 
was explicit. In 'A Negro looks at British imperialism', published in 1938, he remarked that 'it is impossible for any progressively minded Negro to isolate himself from the broader aspects of the subject and view the Colour Bar question from the purely personal standpoint'. To do this would be 'superficial'. He recognised that the 'British people, in their typically off-hand way', assumed that black colonials were a natural part of the empire 'in the same way that Mussolini now claims the Abyssinians'. Britons of all classes, he believed, accepted the myths of empire, just as they displayed a 'cultivated aloofness' to foreigners and 'an added aversion to peoples of darker skin'. But issues of racial prejudice were a political matter: 'we do not whine about them'. ${ }^{49}$ James reflected on this, recounting the occasion in 1957 when he had bumped into Padmore on the Charing Cross Road (which James obviously frequented). Padmore burst out in anger: "'There are only two things in the world I cannot take ... One is race prejudice, the other is bureaucracy"' - and then went on to denounce the sins of bureaucracy, while remaining silent on racism. James, however, was surprised that he even mentioned race.

George was a rare example of a certain type - he fought racialism as a social curse, he was ready to put in his place anyone who was personally offensive, but his preoccupation with large political issues left him little time or energy to 'carry a chip on his shoulder'.

In an uncharacteristically open manner, James discussed the self-discipline required to live in, and work politically in, a white society revealing private instances of anguish and fury. ('English people in particular', he claimed without apparent irony, 'are very grateful when they see that you have had every justification for tearing the place apart but refuse to take it.') Throughout his life in England, James indicated, Padmore had been 'master of himself'. In 'the early days' he may have been angered by the 'dumb stupidity of English people on the race question'. 'But you get over it. ${ }^{50}$ 'Getting over it', however, resolved little, and left in place many difficulties - particularly for those colonials who had most successfully learned to embody the civilisation of the colonial power.

In Padmore's case this unease in confronting the home civilisation of the British bequeathed serious political and analytical problems. He never seemed able to decide what relations existed between Britons at home and Britons abroad, whose predispositions he was content to condemn as fascist. Nor was he able to determine whether racism in the metropolis was, in its fundamental forms, confined to 'the ruling class' or whether it was more general. ${ }^{51}$

Some of these difficulties also emerged in the relations between the 
West Indians (Padmore, James, Makonnen) and the Africans (Kenyatta, Nkrumah). Much later, James conceded that, around 1935 in London, there was a 'definite cleavage' between the Africans and the West Indians. West Indians 'were very much more at home in London and with English people'. The West Indians, or the intellectuals amongst them, were sure that this was because they came from societies which were already modern: not as modern, perhaps, as the cities of the metropolis, but modern all the same. This confidence in knowing the colonial civilisation was the reason, according to James, that the Africans perceived the West Indians as 'black white men' ${ }^{52}$

The contrast with Kenyatta is striking. From his first years in London, in 1929 and then again in 1932, Kenyatta adopted the role of colonial gentleman, aspiring to all things English. ${ }^{53}$ By 1938, in a complex transformation, Kenyatta jettisoned this persona and refigured himself as Gikuyu native, repository of the collective memory of his people. This was most evident in the frontispiece to his anthropological study, Facing Mt. Kenya, in which he pictured himself wearing a Colobus monkey-skin and brandishing a spear. This invention of the traditional Gikuyu self was replete with ambiguity. It is clear, though, that for Kenyatta it represented an attempt to extricate himself from the symbolic and cognitive systems of those who colonised him. What James or Padmore made of this is not recorded. We do know, though, that James's opinion of Kenyatta (and in fact of Nkrumah too) was not without a sense of intellectual - West Indian superiority. In telling of Padmore's skill in dealing with 'the more untutored Africans' in London in the 1930s, James admitted that he found Kenyatta 'very trying', believing him to be only 'the second African to have come out of Kenya'. ${ }^{54}$ James, Padmore and the West Indians in general were conscious that they were products of a radically different history. But in their determination to assert the modernity of their colonial homelands they foreclosed for themselves anything akin to the reinvention of the self which Kenyatta undertook: which made it awkward for them to imagine a way of circumventing, in their lived relations, the codes of colonial England.

When the West Indians congregated in Ghana this situation was acted out in sharper form. In November 1957, on the eve of Padmore's departure for Accra, David Pitt hosted a farewell party at his Gower Street surgery in London. Friends clubbed together and presented to Padmore a briefcase - an appropriate accoutrement for the modern man, on his mission to become adviser to the president of a new nation. In Ghana, James wrote, 'the twentieth century and the future were battling with the middle ages and the past'. ${ }^{55}$ The West Indians - principally Padmore, Arthur Lewis and Makonnen - were the cadres of 


\section{GEORGE PADMORE}

modernity, battling with the African past. Makonnen's restless entrepreneurial spirit was ever-active, launching state bakeries one day, hotels for tourism the next. Yet the larger his vision the greater his sense of frustration, for each new project faced an array of difficulties. He regretted the absence of the type of socialist intellectual whom he remembered and admired from his days in Britain - 'the Oxford Greats man', as he put it, 'going off to lose himself in miners' education in Scotland'. ${ }^{56}$ All the accounts of the early years of the Ghanian state reveal how powerfully 'the past' reasserted itself, and how dreadful were the dilemmas which confronted those who took it upon themselves to represent the future.

Padmore's dedication to the complexities of the local situation was offset by his continuing hopes for the imminent continental revolution, in which Ghana would act as handmaiden for independence across Africa. But this did little to diminish local hostility to the West Indians. ${ }^{57}$ Padmore himself was dogged by illness, and - toward the end - by political frustration. He contemplated returning to the West Indies. ${ }^{58}$ In September 1959, mortally ill, he returned to London for medical attention. He died the same month.

Padmore is now a forgotten figure. A handful of West Indians - George Lamming, John La Rose amongst them - strive to pay him public tribute. At the start of the twenty-first century we live in a political world in which colonialism once again is justified by all manner of sophistry. Padmore expressed - and lived - the elementary truth that colonialism has neither moral nor intellectual justification.

\section{Notes}

1 James's 'Notes on the life of George Padmore' were published in The Nation between October 1959 and January 1960, in eleven instalments; remaining copies - in London and Port of Spain - are difficult to track down. Excerpts were included, under the same title, in Anna Grimshaw (ed.), The C. L. R. James Reader (Oxford: Blackwell, 1992). In 1976 James lectured on Padmore in London, which is reproduced as 'George Padmore: black marxist revolutionary' in James's At The Rendezvous of Victory (London: Allison and Busby, 1984). I have also drawn from James Hooker, Black Revolutionary. George Padmore's path from Communism to Pan-Africanism (London: Pall Mall, 1967). I am grateful to all those who attended the symposium which accompanied the preparation of this volume for their responses to an early version of this chapter, and to Winston James; the resulting views are mine alone.

2 Conversation with George Lamming, Atlantis Hotel, Bathsheba, Barbados, 28 August 2001.

3 C. L. R. James, 'Lectures on The Black Jacobins', Small Axe, 8 (2000), p. 109.

4 'George Padmore dead', Nation, 25 September 1959.

5 V. S. Naipaul, The Mimic Men (Harmondsworth: Penguin, 1969), p. 32.

6 Jeremy Murray-Brown, Kenyatta (London: Allen and Unwin, 1979), p. 171.

7 Murray-Brown, Kenyatta, p. 166. 


\section{BILL SCHWARZ}

8 George Padmore, The Life and Struggles of Negro Toilers (London: Red International of Labour Unions, 1931), pp. 82, 125 and 126.

9 This began as The Negro Workers' Review, the organ of the International Trade Union Committee of Negro Workers, in January 1931. From March 1931 it became retitled The Negro Worker. Padmore served as editor from October 1931 to the issue dated August-September 1933.

10 Ras MaKonnen, Pan-Africanism from Within (Nairobi: Oxford University Press, 1973), pp. 102-3.

11 MaKonnen, Pan-Africanism from Within, p. 194.

12 MaKonnen, Pan-Africanism from Within, p. 181.

13 In August 1937 Padmore and James could be found in Hyde Park heckling Garvey; the deployed his own attack on them at the end of the month in the Trinidadian press. See Rupert Lewis, Marcus Garvey. Anti-colonial champion (London: Karia, 1987), p. 270.

14 George Padmore, Africa and World Peace (London: Secker and Warburg, 1937), p. 157.

15 Padmore, Life and Struggles, p. 6.

16 George Padmore, How Britain Rules Africa (London: Wishart, 1936), p. 396.

17 'Fascist terror against Negroes in Germany', Negro Worker, 3:4/5 (1933).

18 George Padmore, 'Ethiopia and world politics', Crisis, 42:5 (1935), pp. 138-9 and $156-7$.

19 This was the thesis of Africa and World Peace.

20 George Padmore, 'Abyssinia, the last of free Africa'; 'Abyssinia betrayed by the League of Nations'; 'Hitler, Mussolini and Africa'; 'A new world order for colonies', Crisis, 44:5; 44:6; 44:9 and 44:10 (1937). See too Padmore's contribution on Abyssinia to Nancy Cunard's extraordinary Negro Anthology (London: Wishart, 1934) - a collection with which Padmore was closely involved.

21 Reported in the Nation, 23 October 1959. It wasn't only Africans, nor those who shared his views, who paid obeisance in this way. It's instructive that on his trip to London in autumn 1937 Grantley Adams, from Barbados, felt obliged to meet with Padmore: Adams was so impressed that he tried to persuade Padmore to return to the Caribbean. F. A. Hoyos, Grantley Adams and the Social Revolution (London: Macmillan, 1974), pp. 68-9.

22 This aspect of Padmore's life is manifest in Peter Abrahams's novel, A Wreath for Udomo (London: Faber, 1956). Reminiscences of this period can also be found in Abrahams's The Coyaba Chronicles: reflections on the black experience in the twentieth century (Kingston and Cape Town: Ian Randle and David Philip, 2000); and in Dudley Thompson, with Margaret Cezair Thompson, From Kingston to Kenya: the making of a Pan-Africanist lawyer (Dover, Mass: Majority Press, 1993).

23 C. L. R. James, 'Is this worth a war?', New Leader, 4 October 1935.

24 C. L. R. James, 'Baldwin's next move', New Leader, 3 January 1936.

25 George Padmore, 'Fascism in the colonies', Controversy, February 1938; and see too his 'The Trinidad Report', Controversy, March 1938.

26 Padmore, How Britain Rules Africa, pp. 3-4.

27 George Padmore, 'White workers and black', Controversy, May 1938; emphasis added. Versions of his contributions to Controversy also appeared in New Leader and Crisis.

28 George Padmore, 'Britain's black record' New Leader, 27 September 1941.

29 New Leader, 15 December 1939.

30 George Padmore, 'To defeat Nazism we must free the colonials', New Leader, 25 July 1940 .

31 George Padmore, 'Not Nazism! Not Imperialism! But Socialism!', New Leader, 27 December 1941.

32 On the eve of Munich, Makonnen planned for James, Padmore, Kenyatta and himself to retreat to the relative security of Norway, where - he believed - they could witness the final collapse of the colonial powers: Murray-Brown, Kenyatta, p. 209.

$33 \mathrm{I} / \mathrm{m}$ thinking especially of the traditions represented by those who followed Theodor 


\section{GEORGE PADMORE}

Adorno and Frankfurt critical theory. And, in different mode, the positions which emerged from Jean-Paul Sartre's fusion of existentialism and négritude, for which see especially his Colonialism and Anti-Colonialism (London: Routledge, 2001; first published 1964).

34 Padmore, How Britain Rules Africa, p. 395.

35 It is symptomatic that Padmore was very early on to the case of Earl Erroll, who was murdered in Kenya in 1941 - the so-called Happy Valley scandal. In How Britain Rules Africa he had described Erroll's arrival in Kenya in 1934 as a member of the British Union of Fascists (BUF), hoping to build a local branch. According to Padmore, however, Erroll discovered that the settlers for the most part were 'already full-blooded Fascists', and therefore not in need of outside organisation, leading Padmore to conclude that 'Kenya, together with South Africa, is the most Nazified section of the Empire', pp. 359-60. He returned to Erroll after his murder, designating him the 'fascist Don Juan', in 'The truth about the murdered fascist earl' New Leader, 14 June 1941. The first complete discussion of this episode concentrated on the Don Juan dimension rather than on his involvement with the BUF: James Fox, White Mischief (Harmondsworth: Penguin, 1984). More recently, while trying to show Erroll as morally upstanding, the latest account is much more up-front about the fascism, hinting that Erroll was assassinated by the British owing to his possession of dark secrets to do with very senior figures in the British state: Errol Trzebinski, The Life and Death of Lord Erroll (London: Fourth Estate, 2001).

36 Padmore, 'To defeat Nazism'.

37 Again, this proposition is difficult to see in its historical context. It came about as the result of hard political work. For example: when James reviewed How Britain Rules Africa - although he had been warmly acknowledged in the book itself - he announced that he was 'grievously disappointed' that Padmore, 'a man of African descent', had so underestimated the role of Africans in the making of their own emancipation: New Leader, 29 May 1936. James's own Black Jacobins, about Haiti but directed to the future revolution in Africa, comprised a further instalment in this debate.

38 MaKonnen, Pan-Africanism from Within, p. 123.

39 Padmore, Africa and World Peace, p. ix.

40 C. L. R. James, Nkrumah and The Ghana Revolution (London: Allison and Busby, 1982), pp. 29, 36 and 37. English readers might find the force of these comments tempered by James's addition of a footnote at this point, in which he cites the BBC's Goon Show as one moment of this Herculean struggle.

41 George Padmore (ed.), Colonial and Coloured Unity: a programme of action. History of the Pan-African Congress (Manchester: Pan-African Service, n.d., 1945?).

42 MaKonnen, Pan-Africanism from Within, p. 170.

43 George Padmore, 'L'autobiographie de Kwame Nkrumah', Présence africaine, 12 (1957), p. 31. Padmore was due to speak at the Présence africaine Congress of Negro Writers in Paris, but illness prevented him attending. Padmore's connection to the francophone intellectuals - and to Richard Wright - needs more research. His political impact in France in the 1930s is investigated in Philippe Dewitte, Les Movements Nègres en France, 1919-1939 (Paris: Editions L'Harmattan, n.d., 1986?).

44 James, 'Notes on the life of Padmore', Nation, 4 December 1959.

45 MaKonnen, Pan-Africanism from Within, p. 120.

46 James, 'Notes on the life of Padmore', Nation, 15 January 1960; The Times, 25 September 1959.

47 James, 'Notes on the life of Padmore', in Grimshaw, The James Reader, p. 289.

48 James, 'Notes on the life of Padmore', Nation, 15 January 1960. Dorothy Pizer reviewed James's Black Jacobins (favourably) in Controversy, 28 (1939), and was named as the collaborator on Padmore's How Russian Transformed Her Colonial Empire: a challenge to the imperial powers (London: Dennis Dobson, 1946).

49 George Padmore, 'A Negro looks at British imperialism', Crisis, 45:12 (1938), pp. 396-7, emphasis added. For Moody's response to Padmore, see Harold Moody and W. B. Mumford, 'Reply to George Padmore', Crisis, 47:6 (1940), pp. 174 and 186. 


\section{BILL SCHWARZ}

50 James, 'Notes on the life of Padmore', Nation, 8 January 1960.

51 Padmore's views veered from a populist regard for the good sense of the British people, and exasperation. For the former, for example: George Padmore and Nancy Cunard, The White Man's Duty (London: W. H. Allen, 1943), especially p. 33; and James, 'Notes on the life of Padmore', Nation, 8 January 1960. And for the latter, for example: George Padmore, 'The second world war and the darker races', Crisis, 46:11 (1939), pp. 327-8.

52 James, 'Notes on the life of Padmore', Nation, 6 November 1959.

53 For a wonderful account, from which I have learned much, see Simon Gikandi, 'PanAfricanism and cosmopolitanism: the case of Jomo Kenyatta', English Studies in Africa, 43:1 (2000), pp. 3-27.

54 James, 'Notes on the life of Padmore', Nation, 30 October 1959; and James, 'Padmore: black marxist revolutionary', pp. 257-8.

55 C. L. R. James, Nkrumah and the Ghana Revolution (London: Allison and Busby, 1977), p. 85. There is much rich material here both on the West Indian view of Ghana and (when James reflects on Dostoyevsky, Kierkergaard, Nietzsche and Sartre) on the role of intellectuals.

56 MaKonnen, Pan-Africanism from Within, p. 198. As this quote indicates, there was a generational divide. Kamau Brathwaite, of a distinctly younger generation, represents a very different (and very intriguing) West Indian experience of Ghana.

57 There are photographs of Padmore in West African dress, though they are nothing like those of Kenyatta - not least because of Padmore's refusal to relinquish his pipe. The image of the young Malcolm Nurse on his wedding day was not as distant as the African setting might seem to suggest. See Kwame Nkrumah, Hands Off Africa!!! Some famous speeches (Accra: Kwabena Owusu-Akyem, n.d., 1960?). This also carries a photo of Nkrumah receiving Padmore's ashes.

50 MaKonnen, Pan-Africanism From Within, p. 259. 